\title{
Entelektüel Sermayenin Ölçülmesi, Finansal Tablolara Yansıması ve Raporlanmasına Yönelik Bir Araştırma
}

\author{
A Research on the Measurement of Intellectual Capital, Its Reflection on Financial Statements and \\ Reporting
}

Sevgi SÜMERLİ SARIGÜL

Dr. Öğr. Üyesi, Kayseri Üniversitesi, MYO,

ssumerli@erciyes.edu.tr

https://orcid.org/0000-0002-3820-6288
Makale Başvuru Tarihi: 16.07.2020

Makale Kabul Tarihi: 31.08 .2020

Makale Türü: Araştırma Makalesi
Anahtar

Kelimeler:

Entelektüel

Sermaye,

Entelektüel

Sermaye Ölçüm

Yöntemleri,

Muhasebe,

Muhasebe Bilgi

Sistemi,

Keywords:

Intellectual Capital,

Intellectual Capital

Measurement

Methods,

Accounting,

Accounting

Information System,

\section{ÖZET}

Günümüzde entelektüel sermaye kavramı işletmeler için önemli bir kavram haline gelmeye başlamıştır. Teknolojinin hızla ilerlemeye başladı̆̆ bilgi çağında maddi olan varlıkların maddi olmayan varlıkların önüne geçtiği gözlemlenmektedir. Entelektüel sermayenin unsurlarından biri olarak kabul edilen insan sermayesi maddi olmayan varlıkların en önemlilerinden biri olarak kabul görmektedir. Günümüz koşullarında işletmeler varlıklarını devam ettirebilmek, değer oluşturabilmek ve pazar hacimlerini genişletebilmek için üretim faktörlerinden daha önemli olarak bilgiye ihtiyaç duymaktadır. Bilgi, bugün işletmelerin fark yaratmasını sağlayan, onlara maddi faktörlerden çok daha fazla katma değer să̆layan en önemli unsur durumundadır. Yaşanan bu değişimin sonucu olarak işletmeler artık yatırımlarının büyük klsmını, herkesin sahip olabileceği maddi faktörler (fiziksel sermaye, finansal sermaye) yerine bilgiye yani entelektüel sermaye kavramına yapmaktadır. Bu çalışmanın amacı entelektüel sermaye kavramının, unsurlarının, ölçme yöntemlerinin ve muhasebe sistemi üzerinden raporlanabilirliğinin incelenmesidir.

\section{ABSTRACT}

Novadays, the concept of intellectual capital has become an important concept for businesses. It is observed that in the information age, where technology is advancing rapidly, tangible assets outstrip intangible assets. Human capital, which is considered as one of the elements of intellectual capital, is regarded as one of the most important intangible assets. In today's conditions, businesses need information more important than production factors in order to continue their existence, create value and expand their market volumes. Information is the most important element that enables businesses to make a difference and provides them with much more added value than financial factors. As a result of this change, businesses now invest most of their investments in the concept of intellectual capital, rather than material factors (physical capital, financial capital) that everyone can have. The purpose of this study is to examine the concept of intellectual capital, its elements, together with its measurement methods and to examine its reportability in the accounting system. 


\section{GIRISS}

Küresel dünyada firmalar yalnızca maddi imkânlarıyla değil, bilgi ve teknoloji üretimlerine bağlı olarak da güçlü hale gelebilmektedirler. İnsanın diğer canlı türlerinden ayrıldığı temel özelliklerden biri de bilginin üretimine, biriktirilmesine, kullanımına ve paylaşımına yönelik yetkinliğe sahip olmasıdır. Bu nedenle "bilgi" ve "zekâ" rekabet gücü bulunan, çağdaş ve kendisini devamlı yenileyen işletmelerin temel varlıklarından birisini oluşturmaktadır. Şimdi ise bilgi çağı, tartışmasız bir şekilde endüstriyel çağın yerini almaktadır. Bunun kanıtı ise, şirket varlıklarının gün geçtikçe daha büyük bir kısmının bilânçoda bulunamamasıdır. Bilgi, rekabette avantaj sağlamanın temel kaynağıdır; bir şirket yönetiminin, fiziki ve maddi varlıkların yönetilmesinden daha çok insanların yönetilmesi durumuna gelmekte olduğu anlaşılmaktadır. Günümüzde şirketler üretimini gerçekleştirdikleri değerlere oranla varlıklarının yalnızca sınırlı bir kısmını bilânçolarında göstermektedir ve daha geleneksel şirketlere göre genellikle farklı stratejiler uygulamaktadır.

Bilişim çağı, işletmeleri fiziki yapı varlıklardan daha çok bilgi kaynaklı maddi olmayan varlıkların edinilmesine yöneltmektedir. Global dünyada hız kazanan değişimin beraberinde, geleceğin stratejilerinin şekillenmesini sağlayacak olan işletme yönetimi için; güncel değişimin takip edilerek, gerekli kararların yeri ve zamanı geldikçe alınması zorunluluğunu getirmesi kaçınılmazdır. Bugünün koşullarında bir organizasyonun analizini gerçekleştirmeye ilişkin uygulanan yöntemlerde, çoğunlukla finansal rakamların esas alındığı görülmektedir. Fakat geleneksel yapıdaki muhasebe sistemimizin ve bu sistemle elde edilen raporların; fiziki özellik taşımayan varlıkların bilgi kullanıcılarına sunulması noktasında yetersizliği ortaya çıkmaktadır. Yatırımcıların, en başta halka açık işletmelerin finansal tablolarında yeri bulunmayan fiziksel varlıklarıyla ilgili bilgilerine ulaşabilmek için daha başka kaynaklara yönelmeleri, söz konusu işletmeleri olumsuz etkilemektedir.

İşletmeye ilişkin stratejilerin geliştirilmesinde görev alacak yönetim ekibinin ihtiyacı olan bilgi gereksinimini; maliyet esasına dayanan ve özellikle maddi varlıkları ağırlıklı olarak ele alan bir muhasebe sisteminin ve bu sistemin sonucu olarak hazırlanan finansal tabloların karşılaması olanaklı görünmemektedir. Çünkü yürürlükteki muhasebe sisteminin maliyet temelini esas alarak sunduğu bilgiler doğrultusunda, belirlenen işletme değeri ile piyasa tarafından işletme için ortaya konulan değer arasında önemli ölçüde bir farkla karşılaşmak mümkün olabilmektedir. İşletmenin değerine yönelik doğru bir belirleme yapılamayan bilgilere göre geleceğe ilişkin kararlar almak, daha sonra alınması gerekebilecek kararların sorun yaratma olasılığını artıracaktır. Karar almada kullanılacak bu bilgiler, yalnızca yöneticilerin geleceğe ilişkin kararlarını etkilemekle kalmayıp; yatırımcıları, kredi kuruluşlarını ve ortakları da kapsayacak şekilde işletmeyle doğrudan veya dolaylı ilgisi olan bütün çıkar gruplarını kararları hususunda etkilemekte ve ilgilendirmektedir.

$\mathrm{Bu}$ bağlamda gerçekleştirilen bu çalışmanın amacı, bilişim çağı işletmeleri tarafından edinilen entelektüel değerlerin; ne anlam taşıdıkları, hangi ögelerden meydana geldikleri, ölçümlenmeleri, muhasebeleştirilmeleri ve finansal tablolara nasıl yansıtılabilecekleri hususlarının incelenmesidir. Çalışma 4 bölümden oluşmaktadır. Birinci bölümde entelektüel sermaye ve gelişimi konusunda bilgi verilmiştir. Entelektüel sermayenin boyutlarını oluşturan insan sermayesi, yapısal ve müşteri sermayesinden bahsedilmektedir. İkinci bölümde entelektüel sermayeyi ölçme yöntemleri, üçüncü bölümde geleneksel muhasebe ve entelektüel sermaye ilişkisi üzerinde durulmuş, Türkiye'deki Tek Düzen Muhasebe Sistemine uyumlu olarak, güncel entelektüel değerlerin, temel alınan finansal tablolara hangi düzeyde yansitılabileceği konusu incelenmiştir. Son bölümde ise sonuç ve öneriler yer almaktadır.

\section{ENTELEKTÜEL SERMAYE KAVRAMI}

Mevcut literatürde, entelektüel sermayenin herkes tarafından kabul gören bir tanımının yapılamaması farklı tanımlamaların ortaya çıkmasına sebep olmuştur. Entelektüel sermaye kavramının tanımından önce "entelektüel" ile "sermaye" kavramlarını ayrı ayrı tanımlamak, konunun daha kolay bir çerçevede incelenmesi bakımından önem taşımaktadır. Entelektüel, batı dillerinden kaynaklı olup; bilim, sanat ve kültürel alanlara ilişkin yüksek düzeyde eğitim görmüş kişi ya da aydın kesimin belirtildiği bir kavram olarak bilinmektedir (Seyidoğlu, 1992:230).

Sermaye kelimesinin anlamı ise, çeşitli bakış açılarına göre farklılıklar göstermektedir. Muhasebe bakımından, "işletme sahiplerinin varlıklar üzerindeki haklarını temsil eder" (Doğan, 2002:274). İktisat bilimine göre, "mal veya hizmet üretimi için kullanılan üretilmiş olan üretim araçları"; işletme biliminin bakış açısına göre ise, "işletme amaçları ve üretim çabaları doğrultusunda sahip olunan bütün maddi ve maddi olmayan varlıkların toplamıdır" (Çıkrıkçı ve Daştan, 2002:19-20), şeklinde tanımlanabilir. 
Entelektüel sermaye (ES) Latinceden gelen bir kelime olup, ilişkilerin ifade edildiği "inter" ve okuma, bilgi edinme anlamındaki "lectio" kelimeleri ile birikimin, toplamın karşılığı olan "capital" kelimelerinin bir araya getirilmesiyle oluşturulmuştur (Arıkboğa, 2003). Kısaca ES bütün ilişkiler ağının yönetimi sonucu toplanabilen bilgi birikimi anlamında kavramsallaştırılmaktadır. Yönetim gurusu Drucker’ın dediği gibi, "işin manası müşteriler için katma değerli ilişsiler kurmak olduğuna göre, her işin sadece iki temel öğesi vardır: pazarlama ve yaratıcıllk". Bu sebeple, ilişkiler yönetimi ile bilgisel yönetimi de kapsayan ES yönetimi iş hayatında başarı için temel ögedir (Argüden, 2005:9).

ES statik özellikli bir varlık olmayıp; işletmenin gereksinimleri doğrultusunda uygulanabilen, ekonomik ve sosyal bakımdan da dinamizmi ifade eden bir kavramdır. Geleneksel muhasebe anlayışı çerçevesinde, entelektüel sermayenin şerefiye olarak kabul edildiği görülmektedir (Büyüközcan, 2002:36). Piyasada işletme bütünsel bir yapı kapsamında değerlendirilmekte olup, piyasaya göre işletmenin fiyatı ile elde ettiği varlıklar toplamının değeri arasında oluşan fark şerefiye olarak isimlendirilmektedir. Ama günümüzdeki uygulamada durum çok farklıdır. Klasik muhasebe anlayışına göre; maddi olmayan varlıkların ve şerefiyenin amortismana tabi olduğu ve bir süre sonra değerlerini yitirdikleri bilinmektedir (Papatya, 2002:54). ES kapsamında olmak üzere; entelektüel varlıklar, işletmelerin sahiplik hakların iddia edebilecekleri, kısmî olarak maddi bir kimlikle vasıflandırılmış veya fiziksel bir anlam ile tanımlanmış, işletmeye ait bilgidir (Töre, 2019:278).

\subsection{Entelektüel Sermaye Kavramının Gelişimi ve Açıklaması}

İlk olarak 1960'lı yıllar içinde gündeme gelmeye başlayan ES kavramı, 1969 yılında ilk kez J. Kenneth Galbraith tarafindan kullanılmış; değişen işletmelerin organizasyonel yapılanma sürecinde (Ölçer ve Şanal, 2007:480), entelektüel sermaye kavramı ise, 1991'de ilk defa, Thomas Stewart'ın çalışması olan "Beyin Gücü” başlığına sahip makalesiyle ortaya çıkmıştır. Entelektüel sermaye kavramı, bu makalede, "İşletmeye, piyasa koşullarında yapılan rekabet için avantaj sağlayan, işletmede çalışanların bildikleri her şeyin bütünü” (Stewart, 1991:47) ifadesi ile tanımlanmaktadır. Daha sonrasında ise yıllarca ilgi gösterilmeyerek, daha popüler olan başka örgütsel konular kapsamında yer verilmesi nedeniyle dikkatlerden uzak kalmıştır.

Organizasyonlara ilişkin yeni değerlerin yaratılması ve bunların rekabetçi güce yansıtılabilmesinde mevcut kaynakların nasıl daha etkin kullanılmasının mümkün olabileceği, elde bulunan kaynaklar ile daha etkin sonuçlara nasıl ulaşılabileceği sorularının yanıtlarını arama hedefiyle 1980'de, Japonya'da konu tekrar gündeme getirilerek irdelenmiştir. Entelektüel sermaye kavramsal olarak bu gündemin temelini oluşturmuştur (Harrison ve Sullivan, 2000:33; Kanıbir, 2004:78).

1990'dan başlayarak devam eden, bilgi teknolojilerine ilişkin gelişmeler ve yanı sıra küreselleşme, işletmelere yönelik rekabetin artışına neden olmuş ve yeni ekonomik alanın üretimde temel unsuru olarak ES'yi gündeme getirmiştir (Harrison ve Sullivan, 2000:34). ES; zenginliğin oluşturulması adına bilginin kullanılması, entelektüel mülkiyet enformasyon, enformasyon ve deneyim anlamlarına gelmektedir (Odabaşığlu, 2019:1).

Kavrama yönelik çeşitli tanımlamalar yapılmakla beraber, bu tanımlamalarda içeriğin esası bakımından belirgin bir anlam farklılığı görülemediği de anlaşılmaktadır. Dikkate değer bir husus ise, bu konu ile ilgili ileri sürülen tanımlamalarda çoğunlukla aynı kaynaklara atıfların yapılmasıdır (Emrem, 2004). Genel olarak tanımlarda atıf yapılan ve en başta gelen referans kaynağı gösterilen Thomas Stewart entelektüel sermayeyi; "zenginlik yaratmak amacıyla kullanıma alınabilen her türlü entelektüel malzemedir", ifadesini kullanarak belirtmektedir (Stewart, 1997:20; Kanıbir, 2004:78).

Chen (2008) tarafından ES; "bir firmanın mükemmelliği gösteren amaçlarına ulaşması için, değer oluşturan ve rekabette avantaj sağlayan görünmeyen varlıklarl, bilgi ile yeteneklerinin bütünü” (Chen, 2008), olarak ifade edilmektedir. Birbirinden farklı birçok tanımın bulunmasının sebebi; özellikle rekabet koşullarında örgütlere ayrıcalık kazandıran varlıklarının, çeşitli sektörler için değişik nitelikler halinde ortaya çıkmalarıdır. Entelektüel sermaye kavramına göre varlıklar dört grupta toplamaktadır (İşevi ve Çelme, 2005:257-259);

- Ticari Marka: Düşünsel entelektüel mülkiyet kapsamında bulunan patent, telif hakkı gibi varlıkları içermektedir.

- Tüketici Bağlllığı: İç sistemlerden elde edilen güç, yönetimsel ve bilgisel süreç, işletme kültürü gibi organizasyona iç güç sağlayan varlıkları kapsamaktadır.

- Tekrarlanan İşler: Bilişimsel ağ kapasitesini, çalışma alanına ilişkin bilgi, yetenek, organizasyon vb. gibi örgüt çalışanlarının ortaya koydukları varlıkları içermektedir. 
- Pazar Bölümü: işletmeye güç kazandıran varlıklar, insan odaklı varlıklarla beraber, işletmenin başarıya götürülmesine yönelik taktikler ve stratejilerle ilgili faaliyetler bilgi yönetimi içeriğinde incelenmektedir. Tipik olarak birbirine benzeyen yetenekler, çalışanların eğitimi, know-how, kazanılan tecrübelerle öğrenim vb. konuları kapsamaktadır.

\subsection{Entelektüel Sermayenin Unsurları}

ES, şirketlerin hedefleri doğrultusunda değer yaratıp, rekabette üstünlük olanağı tanıyan; maddi olmayan varlıklar ile bilgi ve becerileri belirten bir ifadedir (Özdemir ve Kaya, 2019:269). Dünyada ilk olarak entelektüel sermaye içeriğiyle bir rapor hazırlayan ve yayımlayan, İsviçre kökenli Skandia Şirketi'ne göre entelektüel sermaye, "insan" ve "yapısal" ögeleriyle iki bileşenden oluşmaktadır. Raporda yapısal sermayenin de kendi içinde müşteri sermayesi ve organizasyonel sermaye şeklinde iki bölüme daha ayrıldığı; bu bölümlerden organizasyonel sermayenin de yenilik sermayesi ile süreç sermayesi olarak tekrar iki alt bölüme ayrıldığı belirtilmektedir (Büyüközcan, 2002:37). Bu sınıflandırmaya yenileme ve gelişme sermayesi isimleriyle ilaveler de yapılmaktadır. Bu çalışmada entelektüel sermaye unsurları, yapılan literatür taraması ve alanın genel görüşü çerçevesinde, üç başlığın altında; insan sermayesi, yapısal sermaye ve müşteri (ilişki) sermayesi olarak incelenecektir.

\subsection{1. İnsan Sermayesi}

Çalışanların bireysel yetenekleri, geçmişteki deneyimleri, özel ilgi ve beceri alanları, bireysel ya da grupsal olarak (Gallego ve Rodriguez, 2005:107) belli konular üzerinde uzmanlaşmaları dikkate alındığında; firma işgörenlerini temsil etmekte olan insan sermayesi önemli bir kaynak olarak değerlendirilmektedir (Chen vd., 2004:202). Başarının süreklilik kazanmasında firmanın bilgisinin, becerisinin ve deneyimlerinin artırılmasını sağlamak, bir başka deyişle çalışanların kişisel gelişimlerine katkı sunabilecek yatırımları önemsemek gerekli görülmektedir (Stewart, 1997:95).

İşletmeler, temel amaçlarından olan kârlılık kapsamında kullanabilecekleri ölçülerde insan sermayesi elde etmek istemektedirler. İnsan sermayesi, işletmeler tarafından mülkiyet hakları kapsamında değerlendirilemeyeceği için, sahiplik de söz konusu edilemez, işletme çalışanları işletmeden ayrıldıkları zaman kendileri ile birlikte gider (Gallego ve Rodriguez, 2005:107). Fakat işletme bünyesinde veya dişardan bu işletme için çalışan bireylerin sahip olduğu bilgi ve becerilerden yararlanabilirler. İşletmeler bireyleri kendi kurumları için çalıştırabilir, ama asla sahip olma hakkı elde edemezler. Bu sebeple, var olan insan sermayesinin işyerinde tutulabilmesi için, sürekliliğin ve aitlik duygularının pekiştirilerek, çalışanların işletmeye bağlanmalarını sağlamak gerekmektedir (Yereli ve Gerşi1, 2005:18-19).

\subsubsection{Yapısal Sermaye}

Yapısal sermaye bütünüyle; bilgi birikimi ve bilgiye ulaşabilme ve bilgiyi kullanabilme yetisi, işletme kültürü, işletme sistemi, işletmelerin ticari sırları, ürün tasarımları ve patentlerin toplamıdır (Çıkrıkçı ve Daştan, 2002:22; Önce, 1999:29). Daha basit ve genel bir ifadeyle; işletme çalışanlarının entelektüel çabalarının sonuçlarıdır (İșevi ve Çelme, 2005:260).

Yapısal sermayenin iki temel amacı bulunmaktadır. Bunlardan birincisi ve en önemlisi bilgi aktarımının düzenlenmesi ve bilgi kaybının önüne geçebilecek önlemlerin alınmasıdır. İkincisi ise; işgörenlerin bilgilerin tamamına ve gereken miktarda veriye zamanında ulaşabilmelerinin sağlanmasıdır (Bozbura, 2004:358).

\subsubsection{Müşsteri (İlişki) Sermayesi}

Kurumun ilişki içinde bulunduğu kişi kurum ve kuruluşların tatmini ve bunların kuruma olan bağlılıklarıdır. Firmalar nasıl ki belli zamanlarda organizasyonel yapılarına ve elemanlarına yatırım yapıyorlarsa, müşterilerini de elde tutmak ve kaybetmemek için yatırım yapmak zorundadırlar.

Müşteri sermayesi, örgütte pazarlama kanallarının ve müşteri ilişkilerinin aracı rolü ile bilgilerin geliştirilmesidir. Firmanın içsel ve dışsal çevresi ile olan ilişkilerinin düzenlenmesi ve yönetimi, müşteri ilişkileri, müşteri memnuniyeti, müşteri sadakati, tedarikçiler, rakipler, marka, imaj, lisans anlaşmaları, 
doğrudan dağıtım kanalları ve toplum (Acar ve Dalgar, 2005:28; Görmüş, 2009:66; Özer ve Özer, 2012:471471) gibi unsurların tümü müşteri sermayesini meydana getirmektedir.

Müşteri sermayesi değer bakımından, ödemelerin müşteriler tarafından yapıldığı göz önünde bulundurulursa; insan sermayesi ve yapısal sermaye değerlerine kıyasla daha belirgin bir durumdadır (Stewart, 1997:158-159). Müşteri sermayesi; işletmenin pazar payı, pazarda edindiği yeni müşterileri, halihazırda işletmenin portföyündeki mevcut müşterileri, dağıtılan kar payı ve müşteri tatmin araştırmaları ile daha kolay bir biçimde incelenme imkanı kazanmaktadır (Önce, 1999:19). Bilgi akışı için işletmenin müşterilerinin de dâhil edilmesi firmaya yararlı olacaktır. Belirli konularda bilgilendirilip, yetki dahi verilebilecek müşteriler, organizasyonun ve kendilerinin gelişimine pozitif katkılar sunabileceklerdir (İşevi ve Çelme, 2005:261-263).

\section{ENTELEKTÜEL SERMAYENIN ÖLÇÜLMESI}

Entelektüel sermaye, işletmelerin yer aldıkları pazarda rekabet edebilmeleri için ve piyasadaki varlıklarını korumaya yönelik olarak önkoşul durumuna gelmiştir. Bu kadar öneme sahip olduğu halde mali tablolarda yer almayan bu değerlerin ölçülmelerinin, değerlendirilmelerinin sağlanması gerekmektedir (Şanal, 2006:43).

ES'nin işletmeler temel alınarak ölçülmesi için kullanılan kavramlara ilişkin bazı açıklamalara aşağıda yer verilmektedir. $\mathrm{Bu}$ bağlamda işletmelere ait toplam piyasa değerlerinin içeriğinde bulunan ES payının gösterilmesi mümkün olurken, ögeler bakımından sağlanan değerlerin ayrı ayrı ortaya konulamadığını belirtmek gerekmektedir. Söz konusu açıklamalar doğrultusunda firmaların pazar kapsamındaki değerinin hangi tutarda olduğu anlaşılabilmekte ve başka firmalarla karşılaştırmalar yapılmasını da mümkün hale getirebilmektedir (Bölükbaşı, 2014:431).

İşletmelerin entelektüel sermayelerini ölçmek için; entelektüel sermayenin bileşenlerine ve işletme düzeyine göre ölçümlenmesi olarak iki temel yaklaşım ileri sürülmektedir (Asomedya, 2003). Birinci yaklaşım entelektüel sermaye bileşenlerinin birbirinden bağımsız ölçülüp, izlenmesini; ikinci yaklaşım ise söz konusu bileşenlerin bütünsel olarak değerlendirilmesini, ölçülmesini ve izlenmesini öngörmektedir (Stewart, 1997:296325; Uzay ve Savaş, 2003:167).

Entelektüel sermayenin işletme düzeyinde ölçülmesi için ön değerleme yöntemleri adıverilen başlıca üç farklı yöntem kullanılmaktadır. Bunlar sıralandığında; piyasa değeri/defter değeri oranı ve Tobin'in Q oranı ile maddi olmayan varlıkların değerlerinin hesaplanması olarak görülmektedir. Ölçme için kullanılan bu yöntemlerin ortak noktasını ise; hisse senedi piyasasının şekillendirdiği işletme değeri ile işletme bilançosunda görülen değerin kıyaslanmasıyla belirleme oluşturmaktadır.

$\mathrm{Bu}$ yöntemlerle entelektüel sermaye (ES) yönetimi olduğu işletmeye bildirilmeden önce, ES'nin var olup olmadığı saptanmaktadır. ES bileşenlerinin blok halinde ölçülmesinde kullanılan ikinci kısım yöntemlere ise sürekli değerlendirme yöntemleri adı verilmektedir ve işletme varlıklarının belirlenip, değerlendirmeye alınmalarını ve işletmenin performansını artırmayı hedeflemektedirler. Sürekli değerlendirme yöntemleri 3 grupta ele alınmaktadır. Bunlar; Performans Karnesi (Balanced Scorecard), soyut varlıkları izleme ve entelektüel sermaye oranıdır (Uzay ve Savaş, 2003:167).

ES'nin ölçülmesi sonucu, işletme için sağlayacağı faydalar aşağıda yer aldığı şekliyle sıralanabilir (Önce, 1999:31);

- Yöneticilerin, işletmelerinde bulunan entelektüel kapsamdaki varlıklarını finansal tablolarında görülebilir hale getirmeleriyle birlikte kredi veren kuruluşlara işletme sahip olduğu entelektüel varlıklarını teminat olarak gösterebilecek ve bu sayede de işletme borçlanma olanaklarını artıracaktır. Özellikle teknoloji alanında yatırım yapacak olan küçük işletmelerin yatırımlarını gerçekleştirmek için kendilerine gerekli olan sermayeyi bulma olanaklarını artacaktır.

- Piyasa değeri yüksek olan işletmeler satın alınmaya ve birleşmeye yönelik özel finansal durumları için oluşacak yüksek değer kaynağını işletmeye yatırım yapmak isteyen çıkar gruplarına rahatlıkla gösterebilecektir.

- Firmaların piyasadaki rakipleri karşısındaki muhtemel durumlarının analizini gerçekleştirerek üstün yönlerinin ve zayıf taraflarının tespit edilmesinde, zayıf yönleri bulunuyorsa en kısa zamanda geliştirmek için gerekli olan girişimlere yönelmelerine katkı sağlayacaktır. 
- Mevcut halde halka açılmış olan veya açılması düşünülen işletmelerin ES’lerini ve gelecek süreçte oluşturacağ potansiyel gelir etkisini rakamsal olarak ifade etmesi sayesinde, işletmenin hisse senetlerinin fiyatını olumlu yönde etkileyecektir.

\subsection{Entelektüel Sermayeyi Ölçme Yöntemleri}

Entelektüel sermayenin ölçülmesi konusunda bahsettiğimiz üzere başlıca iki yöntem kullanılmaktadır. Bunlardan ilki işletme düzeyinde ölçülmesine yönelik yaklaşımlar diğeri de entelektüel sermaye unsurlarını raporlamaya dayalı yöntemlerdir.

\subsubsection{Entelektüel Sermayenin İşletme Düzeyinde Ölçülmesine Yönelik Yaklaşımlar}

Entelektüel sermaye (ES)'nin işletme düzeyine göre başka bir deyişle finansal temele dayandırılarak ölçülmesinde şu yöntemler kullanılmaktadır. Bunlar (Çıkrıkçı ve Daştan, 2002:24; Uzay ve Savaş, 2003:167; Şamiloğlu ve Özçınar, 2003:168; Arıkboğa, 2003:120; Ercan ve Öztürk, 2003:128-130);

1. Piyasa Değeri - Defter Değeri Oranı,

2. Piyasa Değeri / Defter Değeri Oran1,

3. Tobin' in Q Oran1,

4. Maddi Olmayan Varlıkların Değerlerinin Hesaplanması

5. Ekonomik Katma Değer Yöntemi (Economic Value Added- EVA)'dır.

\subsubsection{Piyasa Değeri - Defter Değeri Oranı}

Entelektüel sermaye ölçümü için kullanılmakta olan en basit yöntem, piyasa değeri ve defter değeri arasındaki farkın bulunmasıyla oluşmaktadır (Arıkboğa, 2003:17). İşletmenin piyasa değeri, dolaşımda bulunan hisse senetlerine ait birim fiyatın, hisse adedi ile çarpımından elde edilen tutarla ifade edilmektedir. Defter değeri ise; net aktifini gösteren tutardan, bütün borç toplamının çıkarılması sonucunda kalan değerden oluşmaktadır (Uzay ve Savaş, 2003:167). Piyasa değeri bütün halinde işletmeye özgü değeri ifade etmektedir. Bir işletme için piyasa değerini, belirlenen bir tarih dikkate alınarak, piyasada işletmeye ait hisse senetleri üzerinde yatırımcıların ödemeye uygun karşıladıkları parasal tutar ortaya koymaktadır (Arıkboğa, 2003:17). Aşağıdaki formülde de görüldüğü gibi piyasa değerinden, defter değeri çıkarıldığında ortaya çıkan fark entelektüel sermayenin tutar olarak hesaplanmasına olanak sağlamaktadır. Yani bir işletmenin piyasa değerinden, işletmenin defter değerini (Muhasebe kayıtlarında görünen kısmını) çıkartırsak, aradaki fark işletmenin sahip olduğu entelektüel sermayenin değerini gösterir.

Piyasa Değeri: Hisse Senedi Fiyatı x Hisse Senedi Sayıs1

Entelektüel Sermaye: Piyasa Değeri - Defter Değeri

Örneğin; bir işletmeye ait, piyasada işleme tabi hisselerin değer toplamı 300 bin TL ve defter değeri 180 bin TL ise, bu işletmenin sahip olduğu entelektüel sermaye tutarı; $300-180=120$ bin TL'dir.

\subsubsection{Piyasa Değeri / Defter Değeri Oranı}

Yukarıdaki örneğimizi tekrar ele alacak olursak; entelektüel sermaye aşağıdaki formül ile rakamsal piyasa değerinin, rakamsal defter değerine bölünme işlemi ile oransal olarak hesaplanabilmektedir (Uzay ve Savaş, 2003:167).

\section{Entelektüel Sermaye: Piyasa Değeri / Defter Değeri}

Bu duruma göre işletmeye ait entelektüel sermaye performansı: 300/180=1,66'dır. 
$\mathrm{Bu}$ hesaplama sonucunda işletmenin varlıklarının \%66 oranında entelektüel sermayeye sahip olduğu ortaya çıkmaktadır. Bu oranın kullanımı ile ilgili başlıca temel üç problemle karşılaşılmaktadır. Birinci olarak hisse senedi piyasasının çoğunlukla değişken bir yapıya sahip olmasından ötürü işletme yönetiminin kontrolü dışındaki faktörlerle karşı karşıya kalabilmesidir. İkincisi zaman zaman hem defter değeri hem de piyasa değeri olduklarından farklı bir biçimde gösterilmektedir. Üçüncüsü ise maddi olmayan varlıların değerinin ötesinde bilgi vermemesidir (Stewart, 1997:228-229).

\subsubsection{Tobin'in Q Oranı}

Tobin'in Q oranı; İktisat alanında Nobel ödülüne sahip olan James Tobin'in geliştirmesi sonucu bu ad ile anılmıştır (Stewart, 1997:300-301). Yatırım kararları için tahminler yapılmasına yönelik geliştirilen bu yöntemde, işletmenin yatırıma ilişkin kararlarının tahmin edilmesinde, faiz oranlarına bağımlı olmaksızın, işletmeye ait varlıkların yerine koyma maliyetleri kullanılmaktadır (Önce, 1999:5). Bu oran, işletme borçları ile özkaynaklarının piyasa değerlerinin, varlıkların yerine koyma maliyetlerine matematiksel olarak oranlaması yoluyla hesaplanmaktadır (Sevil ve Şen, 2000:5; Çetin, 2005:365).

İşletmenin piyasa değeri ile varlıkları yerine koyma maliyeti arasındaki ilişki ölçülmektedir. İşletmenin Göreli olarak etkin bir pazarda faaliyet gösterdiği varsayılırsa piyasa değeri Tobin Q'su kullanılarak aşağıdaki şekilde formüle edilebilir (Arıkboğa, 2003:120).

Piyasa Değeri = Kullanım Seviyesi x Yerine Koyma Maliyeti + Kullanım Seviyesi x Entelektüel Sermaye + e2

Formülde yer alan kullanım seviyesi, piyasa değeriyle ilgili vurgu yapılan potansiyel değerin tutarının ne kadar olduğunun kontrolü için gerekmektedir. Formüldeki e2, işletmenin ya da işletme hisselerinin değerinde kendisini gösteren ve rasyonel ölçülerle açıklanamayan farkın ifade edilmesini sağlamak için kullanılmaktadır (Arıkboğa, 2003:120).

Örneğin; MY Anonim Şirketi'nin piyasa değeri 360 bin TL olduğu, toplam varlıklarının maliyet değerinin 90 bin TL, bu varlıkları tekrar yerine koyma maliyet değerinin ise 120 bin TL kabul edildiği varsayılırsa, Tobin'in Q değeri aşağıdaki gibi hesaplanabilir:

$$
\begin{aligned}
& Q=\text { İşletmenin Piyasa Değeri / İşletme Varlıklarını Yerine Koyma Değeri } \\
& Q=360 / 120 \\
& Q=3
\end{aligned}
$$

Tobin'in Q Oranı, işletmenin elde ettiği ES sebebiyle ulaşabileceği kâr potansiyelini ve rekabet alanındaki üstünlüğünü belirtmektedir. Bu yöntemde işletmenin piyasa değeri, işletme varlıklarının yenilenme maliyetine bölünerek yatırımın reel getirisi hesaplanmaktadır. Yatırımın reel getirisinin yükselmesi, "Q" değerini de yükseltmektedir. Bu durumda işletmenin benzerlerine göre daha üst düzeyde kâr elde ettiği anlaşılmaktadır (Çıkrıkcı ve Daştan, 2002:25; Ercan ve Öztürk, 2003:31-132).

Teknoloji ve insan sermayesi gibi varlıklarla bağlantılı olarak şekillenen yüksek seviyede olan bir "Q" değeri işletmenin söz konusu varlıklardan daha fazlasını edinebileceğini göstermektedir (Arıkboğa, 2003:120). "Q" oranı yüksek işletmelerde yatırım eğilimi artarken, "Q" oranının küçük olma durumunda ise varlığın değerinin yeniden yapılandırma maliyeti yükseleceği için işletmenin yatırım eğilimi azalmaktadır. Bu durumda işletme için varlık bakımından ES sahibi olamadığı, varlıklarının getiri düzeylerinin de yerine koyma maliyetlerini karşılayamadıkları sonucuna varılmaktadır.

Tobin "Q" değeri 1'den yüksek olan firmalar, bir başka firma tarafından satın alınırken avantajlı bir durum söz konusu olurken, Tobin Q değeri 1'in altında olan diğer firmalara gelindiğinde bu firmalar piyasada çok daha kolay satın alınabilmektedir. Uluslararası satın almaların incelendiği birçok çalışmada, şirketin yönetim performansının Tobin Q değeri ile ifade edildiği ve dolayısıyla yatırımcıların bu şirketler hakkında yatırım kararı vermeleri için gerekli olan bilgileri daha kolay edinmeleri ve fikir sahibi olmaları sağlanmaktadır (Canbaş vd., 1997:70). 


\subsubsection{Maddi Olmayan Varlıkların Değerlerinin Hesaplanması}

Maddi olmayan varlıkların değeri; bir işletmeye ait maddi varlıkların, sektörde yer alan benzeri maddi varlıkların sahibi olan diğer firmalar tarafından oluşturulan sektörel ortalamaya göre daha iyi bir performans sergileme gücüne eşittir. Bununla birlikte maddi olmayan varlıkların değeri, maddi varlıkların getirisine ilişkin tutarın hesaplanmasından sonra bu tutardan, sektörel ortalamaya denk gelen kısım eksiltilerek elde edilmektedir (Acar ve Dalgar, 2005:35-36).

Maddi olmayan varlıkların değerinin hesaplanması için kullanılmakta olan bu yöntem adımlar halinde Tablo.1'de sıralanmıştır (Çıkrıkçı ve Daştan, 2002:21). Bu yöntemde verilerin üç yıllık bir dönemi içermesi gerekmektedir.

Tablo 1. Maddi Olmayan Varlıkların Değerinin Hesaplanması

\begin{tabular}{|c|c|c|}
\hline İşlemler & Yapılacak İşlemler & \\
\hline 1. İşlem & Üç yıllık vergiden önceki ortalama kârının hesaplanması. & 125 bin \\
\hline 2. İşlem & $\begin{array}{l}\text { Dönem sonu bilançolarından alınan üç yıllık ortalama maddi varlıklar değerinin } \\
\text { hesaplanır ve net aktif belirlenir. }\end{array}$ & 500 bin \\
\hline 3. İşlem & $\begin{array}{l}\text { Hesaplanan ortalama kâr, maddi varlıklar üzerinden ortalama bir değere } \\
\text { bölünmesi ile maddi varlıklar kârlılık oranı hesaplanır. }\end{array}$ & $\begin{array}{c}\% 25 \\
125 \mathrm{bin} / 500 \mathrm{bin}\end{array}$ \\
\hline 4. İşlem & $\begin{array}{l}\text { Belirlenen üç yıla ait sektörel maddi varlıkların getiri oranının hesaplanması } \\
\text { (ancak şirket getiri oranı sektör ortalamasından daha düşük durumda ise bu } \\
\text { yöntem uygulanmayacaktır). }\end{array}$ & $\begin{array}{l}\text { Sektör Ortalamasinı } \\
\% 20 \text { varsayarsak }\end{array}$ \\
\hline 5. İşlem & $\begin{array}{l}\text { İ̧̧letmenin ortalama maddi varlıklar değeri ile sektörün maddi varlık getiri oranı } \\
\text { ortalamasının çarpılması (Elde edilen sonuç sektörde yer alan bir işletmenin } \\
\text { maddi varlıklardan kazanç sağlayabileceği tutarı gösterecektir. Bu rakam, birinci } \\
\text { adımda hesaplanan vergi öncesi kârdan çıkarılarak, işletmenin ortalama } \\
\text { büyüklükteki bir şirkete göre varlıklarından ne kadar daha çok kazanç } \\
\text { ulaşabileceğini gösterir). }\end{array}$ & $\begin{array}{l}500 \times \% 20=100 \\
125-100=25\end{array}$ \\
\hline 6. İşlem & $\begin{array}{l}\text { Üç yılın ortalama gelir vergisi oranının hesaplanıp, ek getiri ile çarpılması ve elde } \\
\text { edilen bu tutarın, vergiden sonraki büyüklüğe ulaşması için getiriyi belirten } \\
\text { tutardan çıartılması (Vergiye esas oran } \% 33 \text { olarak alınmıştır) }\end{array}$ & $\begin{array}{c}16.75 \text { bin TL } \\
25 \times \% 33=8.25 \\
25-8.25=16.75\end{array}$ \\
\hline 7. İşlem & $\begin{array}{l}\text { Prim tutarının net olarak güncel değer hesabı ( } \mathrm{Bu} \text { nedenle primin, işletme } \\
\text { sermaye maliyetine bölünmesi gerekir. Sermaye maliyeti olarak } \% 10 \text { alınmıştır })\end{array}$ & 167.5 bin TL \\
\hline
\end{tabular}

Kaynak: Stewart, 1997:254-255; Önce, 1999:40-41; Çıkrıkçı ve Daştan, 2002:26.

Tablodaki yedinci adım sonunda ulaşılan sonuç bilânço tutarı 167,5 bin TL'dir. Bu tutar örnekte ele alınan işletmenin sektörde bulunan diğer işletmelere göre daha iyi bir performans sergilemek için, maddi olmayan varlıklarından yararlanabileceği gücün rakamsal olarak ölçümünü göstermektedir.

\subsubsection{Ekonomik Katma Değer Yöntemi (Economic Value Added- EVA)}

EVA; Joel Stern ve Bennett Stewart tarafından 1980'li yılların başında geliştirilen (Topal, 2008:250), faaliyetlerden elde edilen kârın bu faaliyetleri gerçekleştirebilmek için kullanılan sermayenin maliyetini karşılayıp karşıllayamadığını ölçen kapsamlı bir yöntemdir (Otley, 1999:372-373). Bu bakımdan yöntem başarılı bir işletmenin en azından kullanmış olduğu sermayenin maliyeti kadar kâr sağlaması gerektiğini savunmaktadır.

EVA'nın birçok şekilde hesaplanma usulü olmakla birlikte en yaygın olarak kullanılan formülü şu şekildedir (Bayraktaroğlu ve Ünlü, 2009:292; Ertuğrul, 2009:34; Akyüz, 2013:344); 
EVA $=$ Vergi Sonrası Net Faaliyet Geliri $-($ A ğırlıklı Ortalama Sermaye Maliyeti x Tahsis Edilen Sermaye $)$

Formülden de görülebileceği üzere EVA, vergi sonras1 net faaliyet gelirinden tüm sermayenin maliyeti düşüldükten sonra kalan getiriyi ifade etmektedir. Çıkan değer pozitif ise, işletmenin faaliyetleri sonucunda sermayesine değer kattığı, negatif ise sermayesinin aşındığı sonucu ortaya çıkmaktadır (Sümerli Sarıül, 2014:46-47).

\subsubsection{Raporlamaya Dayalı Ölçme Yöntemleri}

Entelektüel sermayenin unsurlarını raporlamaya dayanan yaklaşımlar, entelektüel sermayeyi nicel olarak ele almak yerine; işletmenin ES'sini meydana getiren ögeleri bularak, süreçte bunlarla ilgili ortaya çıan gelişmelerin yakından takip edilmesini, işletme içi ve işletmelerin kendi aralarında karşılaştırma yapmalarına olanak verecek bir biçimde raporlamayı amaçlamaktadır (Ertuğrul, 2003). Entelektüel sermayeyi raporlamaya dayalı yöntemler;

\section{Performans Karnesi (Balanced Scorecard) \\ 2. Maddi Olmayan Varlıkları İzleme Yöntemi \\ 3. Skandia Klavuzu (pusulası)'dur.}

\subsubsection{Performans Karnesi (Balanced Scorecard)}

Finansal olmayan ölçümlerin kullanılmasıyla işletme performansının ölçülmesi amacını gerçekleştirmek üzere ortaya konulan bir yaklaşımdır. 1992 yılında Harward Business Review'de Yaklaşım R. Kaplan ve D. Norton tarafindan yayınlanan bir makale ile ortaya atılmıştır (Kaplan ve Norton, 1992). Bu yaklaşım gerçekte maddi olmayan varlıkların ölçülmesini ve yayımlanmasını hedefleyerek oluşturulmuş bir yöntem değildir. Performans Karnesi yönteminin temelinde, ağırlıklı olarak finansal göstergeye dayalı performans ölçümlerinin artık geçerliliğini kaybettiği fikri yatmaktadır (Calabro, 2001:73).

İşletme başarısının sadece finansal boyut ile değil; ürünlerin müşterilere teslim süreleri, üretimde mükemmelleştirmenin sağlanması ve daha yeni ürünleri geliştirmek gibi konuların da işletme performansında yer alması öngörülmüştür (Akgül, 2004:75). Yöntemin temel amac1, işletmelerin iç performanslarına ilişkin ölçümlerini daha net bir yaklaşım kullanarak çok boyutlu olarak ölçümleme yapılabilmesine olanak sağlamaktır (Sümerli Sarıül ve Savsar, 2018:132).

\subsubsection{Maddi Olmayan Varlıklar İzleme Yöntemi}

Maddi Olmayan Varlıklar Cetveli (IAM) yöntemi, Karl Eric Sveiby’nin geliştirerek ilk olarak Celemi adındaki bir işletmede uyguladığı, entelektüel sermaye (ES)'nin ölçülmesinde kullanılan bir yöntemi ifade etmektedir. IAM yöntemi, maddi olmayan varlıkları ölçmek amacıyla geliştirilmiştir (Ertuğrul, 2003). Tabloda maddi olmayan varlıkların önemli bileşenleri şöyle gösterilmektedir (Sveiby, 1997); 
Tablo 2. Maddi Olmayan Varlıklar Çetveli

\begin{tabular}{|c|c|c|}
\hline \multicolumn{3}{|c|}{ Maddi Olmayan Varlıklar Cetveli } \\
\hline Dış Yapı Göstergeleri & İç Yapı Göstergeleri & Beceri Göstergeleri \\
\hline $\begin{array}{c}\text { Büyüme Göstergeleri } \\
\text { Organik Büyüme } \\
\text { İç büyüme }\end{array}$ & $\frac{\text { Büyüme Göstergeleri }}{\text { İç Yapı Yatırımları }}$ & $\begin{array}{c}\text { Büyüme Göstergeleri } \\
\text { Yetenek Göstergesi } \\
\text { Meslekte Geçirilen Yıl Süresi } \\
\text { Eğitim Düzeyi } \\
\text { Yetenek Gelişimi Devir hızı }\end{array}$ \\
\hline $\begin{array}{l}\text { Yenilenme Göstergeleri } \\
\text { İmaj Arttırıcı Müşteriler } \\
\text { Yeni Müşterilere Satış }\end{array}$ & $\begin{array}{c}\text { Yenilenme Göstergeleri } \\
\text { Yapı Güçlendirici Müşteriler } \\
\text { Yeni Ürün / Hizmet Oranları }\end{array}$ & $\begin{array}{c}\text { Yenilenme Göstergeleri } \\
\text { Yetenek Artırıcı Müşteriler } \\
\text { Eğitim ve Öğrenme Maliyetleri } \\
\text { Farklılık }\end{array}$ \\
\hline $\begin{array}{l}\text { Verimlilik Göstergeleri } \\
\text { Müşteri Başına Karlılık } \\
\text { Müşteri Başına Satış } \\
\text { Kayıp/Kazanç indeksi }\end{array}$ & $\frac{\text { Verimlilik Göstergeleri }}{\text { Destek Personel Oranı }}$ & $\begin{array}{c}\text { Verimlilik Göstergeleri } \\
\text { Meslekte Profesyonelik Oranı } \\
\text { Kaldıraç Etkisi } \\
\text { Çalışan Başına Katma Değer } \\
\text { Uzmanların yarattığı Katma Değer Çalışan } \\
\text { Başına Kazanılan Kâr } \\
\text { Uzman Başına kazanılan Kâr }\end{array}$ \\
\hline $\begin{array}{c}\text { Devamlılık Göstergeleri } \\
\text { Müşteri Tatmin Oranı } \\
\text { Büyük Müşterilerin Oranı Yaş } \\
\text { Yapısı } \\
\text { Sadık Müşteri Oranı } \\
\text { Devamlı Siparişlerin Sıklığı }\end{array}$ & $\begin{array}{c}\text { Devamlılık Göstergeleri } \\
\text { Değer/ Durum Oranı } \\
\text { Organizasyonun Yaşı } \\
\text { Yardımcı İşgören Devir Hızı } \\
\text { Tecrübesiz İşgören Oranı } \\
\text { Kıdem }\end{array}$ & $\begin{array}{c}\text { Devamlılık Göstergeleri } \\
\text { Profesyonel Devir Hızı } \\
\text { Sektördeki Ücret } \\
\text { Kıdem }\end{array}$ \\
\hline
\end{tabular}

Kaynak: http://www.sveiby.com/Portals/0/articles/CompanyMonitor.html, 1997.

\subsubsection{Skandia Klavuzu (Pusulası)}

Skandia modeli, entelektüel sermaye yöntemlerinden birisi olarak Skandia'da geliştirilmiştir. Bu model bir işletmenin uzun zaman varlığını koruması için katkı sağlayan süreçlerin ortaya çıkarılmasını ve kalıcı değerleri oluşturan unsurların beslenmesini hedeflemektedir (Harrison ve Sullivan, 2000:34). ES (entelektüel sermaye) yöneticisi unvanını edinen ilk kişi olarak Leif Edvinsson'un tanımına göre ES kavramı; "Skandia şirketi için piyasadaki rekabette avantaj oluşturacak, profesyonel yetenekleri, müşteri ilişskilerini, organizasyonel teknolojileri, deneyimi ve bilgiyi bir araya getiren bir bütündür", ifadesiyle belirtilmektedir (Edvinsson, 1997:368; Emrem, 2004).

Model, ES’yi genel kabul gören bir çerçevede insan sermayesi, yapısal sermaye, müşteri (ilişki) sermayesi başlıkları içeriği ile incelemektedir (Önce, 1999:56-57). Skandia Kılavuzuna göre performans ile strateji arasında kurulan ilişki üzerinde durulmaktadır. Bu model, ES (entelektüel sermaye)'ye daha değişik bir yaklaşımla bakılabileceğini göstermiş ve hangi kavramların değer yaratmaya ilişkin sürece katkısının olabileceği konusunda gelenekselleşmiş varsayımların ötesine geçmelerine yönelik olarak diğer firmaları da teşvik etmiştir (İncekara ve Kaya, 2012:28; Sümerli Sarıül ve Savsar, 2018:120). 
Model, Performans Karnesinde bulunan finansal, müşteri, süreç ve öğrenme/gelişme boyutlarına ek olarak insan boyutunu da ele almakta (Demir ve Taşkın, 2008:1698-1699) ve modelin değerlendirilmesinde birey ve işletme ile çalışanları tatmin önemli bir yere sahip olmaktadır. Modelde bulunan bütün alanların ve insan kaynaklarının etkileşimiyle birlikte, insan kaynaklarının doğrudan etkisi anlaşılmaktadır (Yeniyurt, 2003:134; Sümerli Sarıgül ve Savsar, 2018:121).

\section{MUHASEBE BİLGI SISTEMI}

Muhasebe bilgi sistemi kavramı; genel muhasebe, finansal muhasebe ya da maliyet muhasebesi gibi geleneksel kabul edilen muhasebe çeşitlerini de içermektedir. Temel yönetim bilgi sistemleri kapsamında bulunan en köklü geçmişe sahip ve en ağırlıklı kabul edilen türü oluşturmaktadır. Bununla birlikte işletmelerin günümüze kadar geliştirdikleri en geniş uygulama alanına sahip ve en iyi bilgi sistemi olabilme niteliği de bulunmaktadır (Acar ve Dalgar, 2005:29).

Muhasebe bilgi sistemi (MBS), işletme açısından uygulanan süreçlerin muhasebeye yansıyan yönünü belirtir. Bir işletmede verilerin işlenmesine ilişkin çalışmalar, işletmenin gerekleştirmiş olduğu faaliyetleri doğrultusunda geçerli verilerin toplanması, bilgiye dönüştürülmesi, içsel ve dışsal bilgi kullanıcılarına bu bilgilerin sağlanması muhasebe bilgi sistemi sayesinde gerçekleştirilir (Sümerli Sarıül, 2018:427).

\subsection{Geleneksel Muhasebe ve Entelektüel Sermaye İlişkisi}

Son yıllarda halka açık olan şirketlerin finansal tablolarının hacmi ve içerikleri büyümesine rağmen faydalılıklarının oldukça azaldığı gerçeği gözlerden kaçmamaktadır. Bu yüzden finansal tabloların fonksiyonlarını en iyi şekilde yerine getirebilmesi için olabildiğince bilgilendirici ve şeffaf olmalarında fayda vardır (Ergun, 2002:1-19).

\subsection{Muhasebe Standartları Çerçevesinde Entelektüel Sermayenin Değerlendirilmesi}

Bir yatırım veya harcamanın varlık olarak değerlendirilip değerlendirilmeyeceği ile ilgili olarak Finansal Muhasebe Standartları Kurulu (FASB) ve Uluslararası Muhasebe Standartları Komitesi (IASC)'nin geliştirdiği bazı kriterler bulunmaktadır. Bir yatırımın ve harcamanın varlık olarak değerlendirilebilmesinde gelecekte faydalı olması, kontrol edilebilirliği ve gelecekte sağlanması olası fayda için geçmişteki bir işlemden ya da olaydan kaynaklanıyor olması gerekmektedir (Erkuş, 2004:307).

UMS 38 Standard1, Araştırma ve Geliştirme (Ar-Ge) harcamalarının kısmi olarak aktifleştirilmesine izin verdiği halde FASB'nin, Ar-Ge Maliyetlerinin Muhasebeleştirilmesi ile ilgili olarak bu faaliyetlerinin gelecekte işletmeye sağlayacağı faydalarının belirsizliği, neden ve sonuç ilişkilerinin eksikliği ve gelecekte bu faydanın ölçülmesindeki yetersizlikler gibi nedenlerden dolayı aktifleştirilmelerine izin vermemektedir (Sönmez, 2004).

Uluslararası Muhasebe Standardı 38'e göre; entelektüel sermayenin üç unsuru ile ilgili bir değerlendirme yapıldığında (Erkuş, 2004:309);

- İnsan sermayesinin geliştirilmesine yönelik eğitim ve geliştirme çalışmaları için yapılan harcamalar ve profesyonel personelin ücretleri,

- Yapısal sermaye doğrultusunda gerçekleştirilen kuruluş ile varlığın yeniden yapılandırılması giderleri,

- Müşteri sermayesi kapsamında yapılan reklâm ve promosyon harcamaları,

- Şirket bir bütün olarak değerlendirildiğinde ise, işletme bünyesinde üretilen şerefiyeler varlıklar kategorisinde değerlendirilememektedir.

\subsection{Entelektüel Sermayenin Ölçme ve Raporlanmasında Yetersiz Kalınan Unsurlar}

Entelektüel sermayenin değerini belirlemek ve raporlamak, diğer bir ifade ile maddi olmayan duran varlıkların parasal bir değerle ifade edilmesi beraberinde potansiyel suiistimallere yol açabilir. Entelektüel sermaye, hesapların denetlenmesi, işlemlerin onaylanması ve ölçülebilmesi konusunda henüz bir standardizasyona sahip değildir (Alagöz ve Özpeynirci, 2007:173). Geleneksel muhasebe sisteminde işletmelerin sahip oldukları maddi 
SÜMERLİ SARIGÜL, Sevgi - Entelektüel Sermayenin Ölçülmesi, Finansal Tablolara Yansıması ve Raporlanmasına Yönelik Bir Araştırma

olmayan varlıkların bir bölümü ölçülerek aktifleştirilebilirken veya direkt gider olarak kaydedebiliyorken, bir bölümü ise ölçülemediğinden finansal tablolara aktarılamamaktadır.

Geleneksel anlayış doğrultusundaki muhasebe sistemi içerisinde ES unsurlarının ölçümleri ve raporlanmasında yetersiz kalınan bazı hususlar mevcuttur. Bunun başlıca nedenleri şunlardır (Yereli ve Gerşil, 2005:21-22; Erkuş, 2004:309-311; Önce, 1999:38);

- Entelektüel sermaye unsurlarının işletme mali tabloları arasında yer alan bilânçoda gösterilmesi, genel kabul doğrultusunda oluşan muhasebe ilkelerinden birisi olan parayla ölçülme ilkesiyle ters düşmektedir.

- Geleneksel muhasebe sisteminde, işletme gelirlerinin tablolara yansitılması için tarihsel maliyetleme sistemi kullanılmaktadır. Fakat ES ögeleri işletme için güncel olarak o anda ve gelecekte fayda sağlayacak katma değer ögeleridir.

- Geleneksel anlayışa göne muhasebenin temel amacı maddi, ölçülebilir varlıkları ölçerek, raporlar elde edilmesini sağlamaktır.

- Geleneksel muhasebe sistemine göre raporlanan gelirler, yerine koyma maliyetine değil, geçmiş maliyetlere dayandırılmaktadır. Bilançoyu meydana getiren ögelerin çoğunun raporlanması ve değerlendirilmesi için tarihi maliyet kavramının esas alınması sebebiyle bilânço içerisinde yer alan birçok unsurun cari değeri doğru olarak yansitılamaz.

- Geleneksel muhasebede elde edilen kazanç, firmaların giderleri aktifleştirme veya maliyet altına alabilme kabiliyetine bağlı olarak değişmektedir. Yeni dönemdeki ticari firmalar için ise araştırma maliyetleri, firmanın gelecekteki başarısı için belki de en önemli belirleyici faktördür. Ancak, Ar-Ge faaliyetleri ve harcamaları, patent alınabilecek bir ürün veya sürecin geliştirilmesi şeklinde sonuçlansa dahi katlanılan birçok maliyet maalesef aktifleştirilememektedir. Bunun sonucu olarak da birçok işletme sahip olduğu çok önemli yer teşkil eden maddi olmayan duran varlıklarını işletme bilançolarında gösterememektedir.

- Geleneksel muhasebe sistemine göre işletmenin varlıkları için dönemler dikkate alınarak yıpranma payı (amortisman) ayrılma zorunluluğu bulunmaktadır. Muhasebe Uygulamaları Genel Tebliği (MUGT), maddi duran varlıklar ile birlikte maddi olmayan duran varlıkların da amortisman kuralına tabi olduğunu belirtmektedir. Ancak bu durum entelektüel sermaye anlayışında geçerli olmamaktadır.

- ES'nin ana niteliğgi işletmenin bütünsel olarak ele alınıp değerlendirilmesidir. Fakat geleneksel muhasebe sistemi işletmenin varlıklarının da borçlarının da ayrı birer unsur olarak değerlendirilmesi gerektiği anlayışını korumaktadır.

\subsection{Entelektuiel Sermaye Tablosu}

Entelektüel Sermaye Tablosu, bir işletmenin hangi maddi olmayan varlıklara sahip olduğunu, neleri satın aldığını, onların tablo tarihi itibarıyla hangi değerde bulunduklarını görebilme olanağı sağlayacaktır (Büyüközkan, 2002:40-43). Entelektüel Sermaye Tablosu'nda yer verilen maddi olmayan varlıkları; markalar, müşteri veri tabanları, patentler, alı̧s/satış sözleşmeleri, yazılım ve bilgi sistemleri, formüller ve tarifeler, ürünlerin dağıtım ağları gibi çeşitli unsurlar oluşturabilmektedir. İşletmenin her yıl bu unsurları tablo üzerinde raporlaması gerekir (Önce, 1999:72-73). Bu tablo işletmelere maddi olmayan varlıklarını sunabilmek amacıyla, bu varlıkların maddi varlıklarmış gibi taklit edilerek gösterilmesi yerine, açık, net ve ayrı olarak sunulabilmesini mümkün kılmaktadır.

\subsection{Entelektüel Sermayenin Temel Finansal Tablolar Aracılığıyla Sunulması}

Finansal tablolar bir işletmenin varlıklarına ve kaynaklarının yapısına, faaliyetlerinin sonuçlarına, dönemsel kâr oluşumuna ve kullanımına benzer konulara ilişkin bilgileri kapsayacak şekilde, muhasebe ilkeleri gözetilerek düzenlenmekte olan tabloları ifade etmektedir. Finansal tabloların düzenlenmesindeki temel amaç, işletmenin finansal durumunun ortaya konulması, faaliyetlerinin sonucu olarak ulaştığı noktanın ve diğer konuların, işletmeyle ilgili olan çıkar gruplarının bilgilerine sunulmasıdır (Önce, 1999:82).

Bilindiği üzere Türkiye'de 1994 yılında MUGT'nin yayımlanmasıyla birlikte yürürlüğe giren Tekdüzen Hesap Planına göre, maddi olmayan varlıklar 26 numara ile Maddi Olmayan Duran Varlıklar hesap sınıfı kapsamında yer almaktadır (Çıkrıkçı ve Daştan, 2002:27). Bu hesaplardan öncelikli olarak 261 Şerefiye Hesabı ele alınacak olursa; şerefiye, işletme tarafından sahip olunan entelektüel sermayeyi ifade etmektedir. Satın alınan tarih 
itibarıyla hesaplanan şerefiye değeriyle, işletmenin entelektüel varlık değeri ortaya konulmuş olsa da yürütülen faaliyetlerin yanı sıra; işletmede üretilen bilginin, geliştirilen sürecin, yöneticilerin başarılarının ve maddi olmayan varlıklar kapsamında yaratılmış olan diğer katma değerlerin gösterilmesini başaramamaktadır (Çıkrıkçı ve Daştan, 2002:27-28). Uluslararası Muhasebe Standardı 38'e göre şerefiyeler ancak işletmelerin birleşmeleri sırasında ortaya çıkarsa varlık olarak kaydedilebilmektedir.

Yine aynı hesap sınıfında bulunan 263 Araştırma ve Gelişstirme Giderleri Hesabı ile ilgili; "işletme tarafindan daha yeni ürünler ile teknolojilerin oluşturulması, var olanlarının geliştirilmesi vb. amaçlar doğrultusunda yapılan her türlü harcamaların, aktifleştirilen kısımlarının takip edildiği hesaptır", ifadesi ile bu hesaba açıklama getirilmektedir (Önce, 1999:71). Bu açıklamalar doğrultusunda görüleceği üzere, işletmelerde var olan entelektüel varlıkların değerlerinin gösterilmesinde yetersiz kalmakta olduğu anlaşılmaktadır. Bu sorun, Tek Düzen Hesap Planı üzerinde, Entelektüel varlıklara ilişkin hesaplamalar, bilânço tarihi itibarıyla ya da her ihtiyaç hissedildiği durumda yapılıp kayıt altına alınabilir ve bilânçoya da yansıtılması mümkündür. Yıllar içerisinde gerçekleşen artışları, ilgili hesaplara belirtilen yöntemle aşağıda yer alan açıklamalar doğrultusunda giderilebilecek durumdadır (Çıkrıkçı ve Daştan, 2002:29).

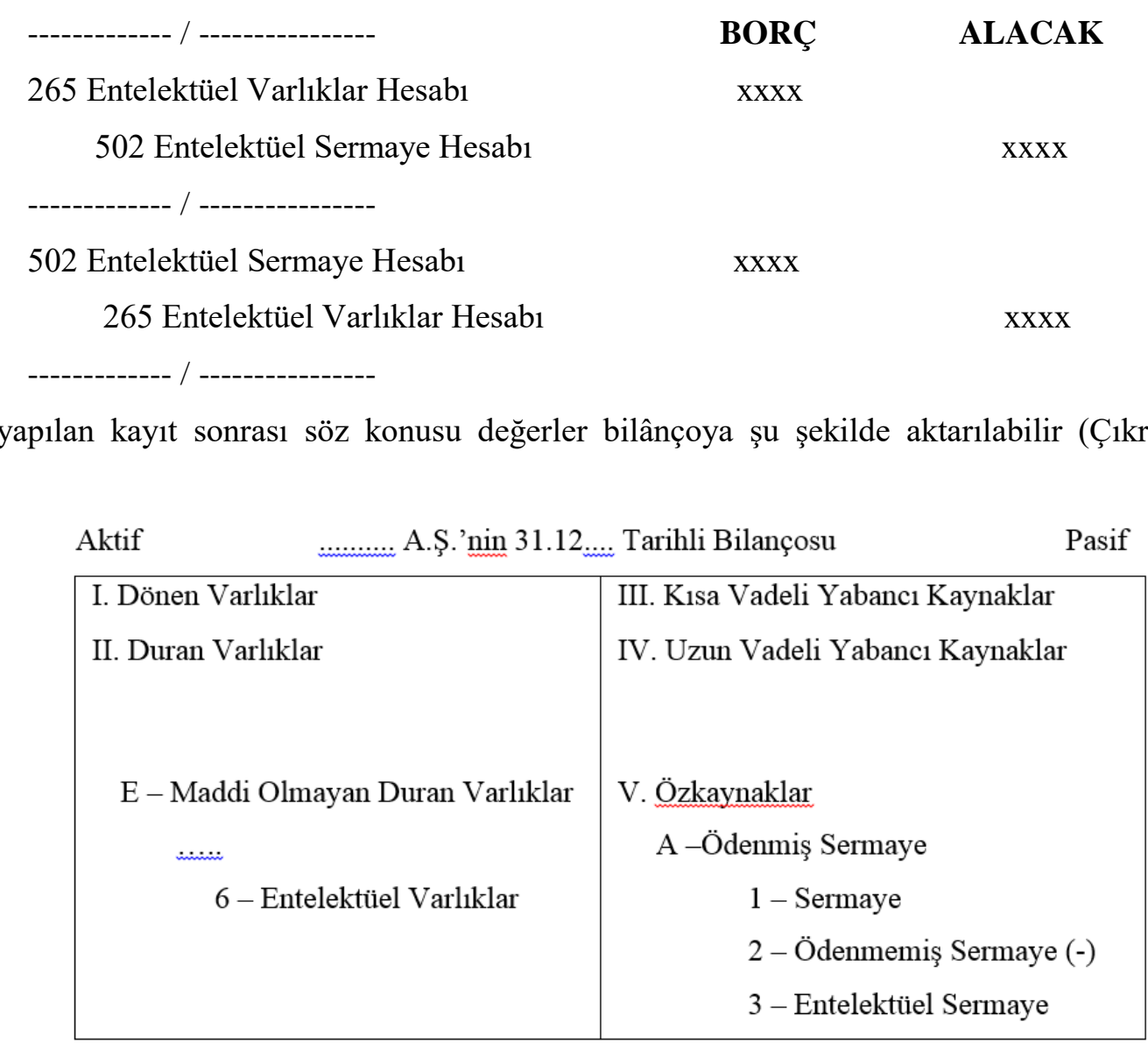

İşletmelerin ellerindeki varlıkları piyasa değerlerini ortaya çıkarmaları dönem sonlarında mümkün olabilir. Şöyle ki: Piyasa Değeri-Defter değeri yöntemini kullanıp hesaplama yaparak, elde edilen fark tutarının ne kadarının bilanço üzerinde gösterilmesi gerektiği ve maddi olmayan varlıklardan olduğunun belirlenmesinin ardından; hesap planında boş bırakılmış olan 265 ve 266 numaralı hesapların üzerinde takibi gerçekleştirilebilir (Acar ve Dalgar, 2005:34-35).

Bilançonun bu usulde düzenlenmesiyle birlikte, faaliyet dönemine ait finansal kârın hesaplanması sırasında sorun meydana gelebilmektedir. Bu soruna; bilânço esasına göre vergiye esas olacak kazancın dönem sonu özsermayesi ile dönem başı özsermayesi arasında gerçekleşen olumlu yöndeki fark tutarına, dönem içerisinde ortaya çıkarak eklenecek değerler ya da eklenen değerlerin çıkartılması sonucunda bulunması neden olmaktadır. Bazı düzenlemelerin yapılmasıyla sorun giderilebilir (Çıkrıkçı ve Daştan, 2002:29). 


\subsection{Entelektüel Sermayenin Yasal Kayıtlarda Gösterimesi}

Güncel mevzut düzenlemelerine göre ES olarak tanımlanan bu kıymetler, kaynak kuruluşta muhasebe kaydına konu edilememektedir. Ancak, pay senetlerinin nominal değerlerinin üzerinde satın alanlarca, satınalma bedellerinin işletme kayıtlarına geçirilmesi mümkün olabilmektedir.

Halen işletmeler gruplarına dâhil bağlı ortaklık ve iştiraklerini bu yolla kayıtlarında gerçeğe uygun değerlerle gösteriyorlar. Özü itibariyle bu birikimlere değer izafe etmek, uygulanan method ve yaklaşımlara göre çok subjektif sonuçlar doğurmaktadır. Ancak, sahiplik haklarının el değiştirmesi sırasında ES, nominal değerlerin üzerindeki ilaveler olarak yasal kayıtlara konu edilmekte, bu farklar payı elinden çıkaran sermaye sahiplerinin kazanç ve kaybını oluşturmaktadır. Entellektüel sermaye unsurlarında meydana gelen bu değer artış ve azalışlar, kaynak kuruluşlarda bu tutarların kayda alınması ne Türkiye Finansal Raporlama Standartları (TFRS), ne de Tek Düzen Muhasebe Sistemi (TDMS)'ne göre mümkün olamadığından gelir veya gider olarak değerlendirilmemelidir. $\mathrm{Bu}$ nedenle bu unsurların yalnızca bilânçoda takip edilmesi ve dolayısıyla gelir tablosuna yansıtılmamasının daha doğru olacağı görülmektedir.

\section{SONUÇ}

Günümüzde işletmelerin etkili bir yönetim sergileyebilmeleri, entelektüel sermayelerini somutlaştırarak ortaya koyabilmeleri için çalıştıkları bilinmektedir. Çünkü etkili bir yönetime ilişkin temel koşul ölçülebilirliğidir. Bu bağlamda işletmeler, entelektüel değerlerinin etkili yönetimine ilişkin olarak, ES'lerini ölçmek durumundadırlar ve bu noktada işletmelerin ES ölçümleri için gereken en önemli katkı muhasebe bilgi sistemi tarafindan sağlanmaktadır.

ES'yi ölçme hedefine ilişkin yöntemler çerçevesinde kullanılan işletme piyasa değeri/defter değeri, maddi ve maddi olmayan varlıklar değerleri, kâr miktarları ve faaliyet giderleri gibi birçok verinin, kaynak niteliğinde olan muhasebe bilgi sistemi kullanılarak elde edildiği bilinmektedir. Bu kapsamda muhasebe bilgi sisteminin, üreterek sunduğu verilerin işlenmesiyle ES ölçümünün mümkün olduğu açık bir halde görülmektedir.

Maddi olmayan varlıklar ile entelektüel sermaye tanımı birbiriyle örtüşüyor görünse de, genelde birbirinden farklı anlamlar içermektedir. Gerçekte bir muhasebe terimi kapsamınca kullanılan ve muhasebeleştirilen maddi olmayan varlıklar da şerefiye gibi entelektüel sermayenin tümünü açıklamakta ve kapsamakta yetersiz kalmaktadır. Bununla birlikte işletmelerin sermaye faktörleri arasında, kendine yer bulan entelektüel sermaye, çağımız işletmeleri için fiziksel ve finansal sermayeye alternatif olarak değerlendirilmektedir.

Özetle, refah düzeyinde artış sağlamak isteyen toplumların ve sahip oldukları değerleri yükseltmek isteyen şirketlerin sermaye düzeylerini ölçmeleri, geliştirmeler sağlamaları, kaynakların yerinde kullanımını, bilgi birikimini geliştirmeye yöneltmeyi, konuya ilişkin girişimlerin teşvik edilmesini ve fikri mülkiyet kapsamındaki hakların oluşturularak korunmasını öncelikleri haline getirmeleri gerekmektedir.

\section{KAYNAKÇA}

ACAR, Durmuş ve DALGAR, Hüseyin (2005), "Entelektüel Sermayenin Ölçülmesinde Muhasebe Bilgi Sisteminin Katklsı", Muhasebe ve Denetimine Bakış, S.4(14), ss.23-40.

AKGÜL, Başak Ataman (2004), "İ̧sletmelerde Yeni Performans Ölçümleme Sistemleri”, Muhasebe Finans Dergisi, S.24, ss.73-82.

AKYÜZ, Y1lmaz (2013), “Ekonomik Katma Değer (EVA) ve Pazar Katma Değer (MVA) Analizi: IMKB'de İşlem Gören Seramik İşletmelerinde Bir Uygulama", Süleyman Demirel Ǘniversitesi İktisadi ve İdari Bilimler Fakültesi Dergisi, S.18(2), ss.339-356.

ALAGÖZ, Ali ve ÖZPEYNIRCİ , Rabia (2007), "Bilgi Toplumunda Entelektüel Varliklar ve Raporlanmasi”, Afyon Kocatepe Üniversitesi İktisadi ve İdari Bilimler Fakültesi Dergisi, S.9(2), ss.167-184.

ARGÜDEN, Yılmaz (2005), Entelektüel Sermaye, ARGE Danışmanlık Yayınları, İstanbul.

ARIKBOĞA, F. Şebnem (2003), Entelektüel Sermaye, Derin Yayınları, İstanbul. 
ASO - ANKARA SANAYİ ODASI (2003), "Entelektüel Sermayenin Firma Değeri Üzerine Ektisi”, ASOMEDYA,https://www.aso.org.tr/kurumsal/media/kaynak/TUR/asomedya/nisan2003/dosyanisan200 3.html (Erişim Tarihi: 03.03.2020).

BAYRAKTAROĞLU, Ali ve ÜNLÜ, Ulaş (2009), "Performans Değerlemede EVA ve MVA Ölçütleri: Bu Ölçütler Açısından IMKB ve NYSE'nin Karşılaştırmalı Analizi”, Süleyman Demirel Üniversitesi İktisadi ve İdari Bilimler Fakültesi Dergisi, S.14(1), ss.287-312.

BOZBURA, F. Tunç (2004), "Measurement and Application of Intellectual Capital in Turkey", The Learning Organization, S.11(4/5), ss.357-367.

BÖLÜKBAȘI, Yunus (2014), "Entelektüel Sermayenin İşletme Bazında Ölçülmesinde Kullanılan Yöntemler ve Sigorta Sektöründe Bir Araştırma”, Marmara Üniversitesi İïBF Dergisi, S.36(1), ss.425-447.

BÜYÜKÖZCAN, Gülçin (2002), “Entelektüel Sermaye Yönetimi”, Kalder Forum, S.2, ss.35-44.

CALABRO, Lori (2001), "On Balance: Almost 10 Years After Developing The Balanced Scorecard, Authors Robert Kaplan and David Norton Share What They've Learned", The Magazine for Senior Financial Executives, S.1, ss.73-76, http://www.cfo.com/article/1,5309,2044,00.html (Erişim Tarihi: 10.04.2019).

CANBAŞ, Serpil, DÜZAKIN, Hatice ve KILIÇ, Süleyman Bilgin (1997), "Türkiye'de Hisse Senetlerinin Değerlendirilmesinde Temel Finansal Verilerin ve Bazı Makro Ekonomik Göstergelerin Etkisi", ERCMETU International Conference in Economics - IV: Conference Proceedings, 13-16 Eylül 2000 Ankara, ss.70.

ÇETIN, Ayten (2005), "Entelektüel Sermaye ve Ölçülmesi”, Marmara Üniversitesi İktisadi ve İdari Bilimler Fakültesi Dergisi, S.20(1), ss.359-378.

CHEN, Jin, ZHU, Zhaohui ve XIE, Hong Yuan (2004), "Measuring Intellectual Capital: A New Model and Empirical Study", Journal of Intellectual Capital, S.5(1), ss.195-212.

CHEN, Yu-Shan (2008), "The Positive Effect of Green Intellectual Capital on Competitive Advantages of Firms", Journal of Business Ethics, S.77(3), ss.271-286.

ÇIKRIKÇI, Mustafa ve DAŞTAN, Abdulkerim (2002), "Entelektüel Sermayenin Temel Finansal Tablolar Aracılı̆̆ıyla Sunulması”, Bankacılar Dergisi, S.43, ss.18-32.

DEMIR, Alparslan Serhat ve TAŞKIN, Harun (2008), "İşletme Performanst Ölçme Modellerinin Karşılaştırılması: Kuantum Performansı, Maddi Olmayan Varlıkların İzlenmesi, Performans Prizması ve Skandia Kllavuzu Modelleri”, Journal of Yaşar University, S.3(11), ss.1695-1709.

DOĞAN, Ahmet (2002), Genel Muhasebe II, Erciyes Üniversitesi İktisadi ve İdari Bilimler Fakültesi Yayını, Kayseri, 3. Bask1.

EDVINSSON, Leif (1997), "Developing Intellectual Capital at Skandia”, Long Range Planning, S.30(3), ss.366-373.

EMREM, A. Erdinç (2004), "Entelektüel Sermaye ve Bileşenlerinin Kavramsal Analizi”, Elektronik İş-Güç Dergisi, S.6(1), http://www.isguc.org/arc_view.php?ex=116 (Erişim Tarihi: 22.03.2019).

ERCAN, Metin Kamil ve BAŞARAN, Öztürk (2003), Değere Dayalı Yönetim ve Entelektüel Sermaye, Gazi Kitapevi, Ankara.

ERGUN, Ülkü (2002), "Yönetsel Performansın Geliştirilmesinde Yeni Yaklaşımlar: Mükemmellik Modeli ve Balanced Scorecard", Muhasebe Bilim Dünyası Dergisi, S.4(1), ss.1-19.

ERKUŞ, Hakan (2004), "Geleneksel Raporlama Yöntemlerinin Yeni Ekonomi Karşısındaki Durumunun İrdelenmesi ve Entellektüel Sermayenin Raporlanmasl", Süleyman Demirel Üniversitesi İktisadi ve İdari Bilimler Fakültesi Dergisi, S.9(2), ss.303-324.

ERTUĞRUL, Murat (2003), "Entelektüel Sermayenin Ölçülmesi ve Raporlanması", Bilgi Yönetimi (EMakale), http://www.bilgiyonetimi.org/cm/pages/mkl_goS.php ?nt= 183 (Erişim Tarihi: 19.12.2019).

ERTUĞRUL, Murat (2009), "Finansal Performans Ölçümünde Dönüşümlerin Türkiye Açısından Değerlendirilmesi”, Anadolu Üniversitesi Sosyal Bilimler Dergisi, S.9(1), ss.19-46.

GALLEGO-ALVAREZ, Isabel ve RODRIGUEZ-DOMINGUEZ, Luis (2005), "Situation of Intangible Assets in Spanish Firms: An Empirical Analysis", Journal of Intellectual Capital, S.6(1), ss.105-126. 
SÜMERLİ SARIGÜL, Sevgi - Entelektüel Sermayenin Ölçülmesi, Finansal Tablolara Yansıması ve Raporlanmasına Yönelik Bir Araştırma

GÖRMÜŞ, Alparslan Şahin (2009), "Entelektüel Sermaye ve İnsan Kaynakları Yönetiminin Artan Önemi”, Afyon Kocatepe Üniversitesi İiBF Dergisi, S.11(1), ss.57-75.

GÜCENME, Ümit (2000), "International Accounting Standart-IAS 38, 'Maddi Olmayan Varlkklar", Muhasebe ve Finansman Dergisi, S.5, ss.99-115.

HARRISON, Suzanne ve SULLIVAN, Patrick H. (2000), "Profiting from Intellectual Capital", Journal of Intellectual Capital, S.1(1), ss.33-46.

İNCEKARA, Ahmet ve KAYA, Yusuf (2012), "Entelektüel Sermayenin Ölçülmesine Yönelik Yöntemler ve İşlevsel Bir Sinıflandırma", 1.Uluslarası Entelektüel Sermayenin Ölçülmesi ve Raporlanması Sempozyumu Bildiriler Kitabı, İstanbul Üniversitesi Yayını, İstanbul, ss.11-40.

İşEVI, A. Semih ve ÇELME, Burçin (2005), "Bilgi Çă̆ında Yeni Hazine: Entelektüel Sermayeyle Rekabeti Yakalamak", Bilgi Dünyası Dergisi, S.6(2), ss.251-267.

KANIBIR, Hüseyin (2004), "Yeni Bir Rekabet Gücü Kaynağı Olarak Entelektüel Sermaye ve Organizasyonel Performansa Yansimaları", Havacılık ve Uzay Teknolojisi Dergisi, S.1(3), ss.77-85.

KAPLAN, Robert S. ve NORTON, David P. (1992), "The Balanced Scorecard: Measures That Drive Performance", Harvard Business Review, S.70(1), ss.71-79.

KAYALI, Cevdet A. ve YERELİ, Ayșe N. ve ADA, Şebnem (2007), "Entelektüel Katma Değer Katsayısı Yöntemi Kullanılarak Entelektüel Sermayenin Firma Değeri Üzerindeki Etkisinin Belirlenmesine Yönelik Bir Araştırma", Yönetim ve Ekonomi: Celal Bayar Üniversitesi İiBF Dergisi, S.14(1), ss.67-90.

ODABAŞOĞLU, Şener (2019), "Havayolu İşletmelerinde Entelektüel Sermayenin Piyasa Değeri-Defter Değeri Oranina Etkileri", Journal of Aviation Research, S.1(1), ss.1-23.

OTLEY, David (1999), "Performance Management: A Framework for Management Control Systems Research", Management Accounting Research, S.10, ss.363-382.

ÖLÇER, Ferit ve ŞANAL, Musa (2007), “İşletmelerde Entelektüel Sermaye Yönetimi”,, Ç.Ü. Sosyal Bilimler Enstitüsü Dergisi, S.16(1), ss.479-500.

ÖNCE, Saime (1999), Muhasebe Bakış Açısı ile Entelektüel Sermaye, Eskişehir Anadolu Üniversitesi Yayınları, Eskişehir.

ÖZDEMIR, Serkan ve KAYA, Yusuf (2019), "Entelektüel Sermayenin Ölçülmesinde ve Raporlanmasında Kullanilan Yöntemler: Türkiye Banka Sektöründe Bir Uygulama", Pamukkale Üniversitesi Sosyal Bilimler Enstitüsü Dergisi, S.35, ss.269-284.

ÖZER, Ali ve ÖZER, Nevin (2012), "Kaynak Temelli Yaklaşım ve Paydaş Yaklaşımı Açısından Entelektüel Sermayenin IMKB'deki Çokuluslu İşletmelerin Finansal Performansina Etkisi”, 16. Finans Sempozyumu Bildiriler Kitabı, Atatürk Üniversitesi Yayını, Erzurum, ss.471-497.

PAPATYA, Gürcan (2002), "Entelektüel Sermaye Asimetrisi: Yönetim İdeolojisine Düşülebilecek Bazı Notlar", İnfo-mag Bilgi ve İletişim Teknolojileri Dergisi, S.15, ss.52-57.

SEVIL, Güven ve ŞEN, Mehmet (2000), "Hisse Senetlerinin Piyasa Değeri ve Finansal Kararlar Arasındaki İlişkilerin Tobin-Q Oranı İle Belirlenmesine Yönelik Bir Uygulama", İktisat-İşletme ve Finans Dergisi, S.15(168), ss.4-12.

SEYIDOĞLU, Halil (1992), Ekonomik Terimler Ansiklopedik Sözlük, Güzem Yayınları, Ankara.

SÖNMEZ, Feriştah (2004), "Maddi Olmayan Duran Varlıklar-MODV (TMS-8, UMS-38, l.Taslak MODV ve SPK Tebliğleriyle Karşılaştırmalı Olarak)", Vergici ve Muhasebeci ile Diyalog Dergisi, S.19(191), ss.123-141.

STEWART, Thomas A. (1991), “Brainpower”, Fortune Dergisi, S.123(11), ss.44-54.

STEWART, Thomas A. (1997), Entellektüel Sermaye Kuruluşların Yeni Zenginliği (Çev. Nurettin Elhüseyni), MESS Yayınları, İstanbul.

SÜMERLİ SARIGÜL, Sevgi (2014), "Geleneksel ve Çok Boyutlu Performans Değerleme Modelleri ve Bir Araştırma", Yayımlanmamış Doktora Tezi, Erciyes Üniversitesi Sosyal Bilimler Enstitüsü, Kayseri. 
SÜMERLİ SARIGÜL, Sevgi (2018), "Pazarlama Muhasebesi ve Müşteri Kârlıllk Yönetimine Yönelik Genel Bir Değerlendirme”, Uluslararası Yönetim Akademisi Dergisi, S.1(3), ss.425-435.

SÜMERLİ SARIGÜL, Sevgi ve SAVSAR, Cihat (2018), "Çok Boyutlu Performans Değerlendirme Yöntemlerine Genel Bir Bakış", Sosyal, Beşeri ve İdari Bilimler Alanında Yenilikçi Yaklaşımlar (Ed. Kürşat Özdaşl1, Murat Cem Demir, Olcay Tire, İbrahim Sena Arvas, Uğur Köksal Odabaş, İsmail ELAGÖZ), Gece Kitaplığı Yayınları, Ankara, Cilt 3, ss.111-143.

SVEIBY, Karl E. (1997), "The Intangible Assets Monitor", Journal of Human Resource Costing and Accounting, S.2(1), ss.24-36, http://www.sveiby.com/Portals/0/articles/CompanyMonitor.html (Erişim Tarihi: 20.10.2019).

ŞAMİLOĞLU, Famil (2002), Entelektüel Sermaye, Gazi Kitabevi, Ankara.

ŞAMILOĞLU, Famil ve ÖZÇINAR, Faruk (2003), "Entelektüel Sermayenin Muhasebe ve Finansman Alanlarında Yarattı̆̆ Yeniden Yapılanma İhtiyacı”, Muhasebe Finansman Dergisi, S.19, ss.128-134.

ŞANAL, Musa (2006), "Entelektüel Sermaye Yönetim ve Türk Yedek Sanayi İşletmelerinde Uygulanmasl Üzerine Bir Araştırma", Yayımlanmamış Yüksek Lisans Tezi, Mustafa Kemal Üniversitesi Sosyal Bilimler Enstitüsü, Hatay.

TOPAL, Yusuf (2008), "Ekonomik Katma Değer (EVA) ve Pazar Katma Değer (MVA) Arasındaki ilişki IMKB Imalat İsletmelerinden Örnek", Süleyman Demirel Üniversitesi İktisadi ve İdari Bilimler Fakültesi Dergisi, S.13(2), ss.249-261.

TÖRE, Esra (2019), “Entelektüel Sermayenin Yenilikçi İşs Davranışına Etkisinde Bilgi Paylaşımının Aracı Rolü”, Yönetim Bilimleri Dergisi, S.17(34), ss.275-299.

UZAY, Şaban ve SAVAŞ, Orhan (2003), "Entelektüel Sermayenin Ölçülmesi: Mobilya Sektöründe Karşılaştırmalı Bir Uygulama Örneği”, Erciyes Üniversitesi İktisadi ve İdari Bilimler Fakültesi Dergisi, S.20, ss.163-181.

YENIYURT, Şengün (2003), "A Literature Review and Integrative Performance Measurement Framework for Multinational Companies", Marketing Intelligence \& Planning, S.21(3), ss.134-142.

YERELİ, Ayşe N. ve GERŞiL, Gülşen (2005), "Entelektüel Sermayeyi Ölçme ve Raporlama Yöntemleri”, Yönetim ve Ekonomi: Celal Bayar Üniversitesi İïBF Dergisi, S.12(2), ss.17-29. 